I NTERNATIONALMONETARY FUND

Research Department

Boosting Fiscal Space

The Roles of GDP-Linked Debt and Longer Maturities

Jun I. Kim and Jonathan D. Ostry

No. $18 / 04$ 
IMF DEPARTMENTAL PAPER

\section{BOOSTING FISCAL SPACE THE ROLES OF GDP-LINKED DEBT AND LONGER MATURITIES}

Jun I. Kim and Jonathan D. Ostry 


\section{Boosting Fiscal Space: The Roles of GDP-Linked Debt and Longer Maturities ${ }^{1}$ \\ Prepared by Jun I. Kim and Jonathan D. Ostry² \\ Authorized for Distribution by Maurice Obstfeld}

\section{Cataloging-in-Publication Data \\ Joint Bank-Fund Library}

Names: Kim, Jun (Jun Il) | Ostry, Jonathan David, 1962- | International Monetary Fund.

Title: Boosting fiscal space : The roles of GDP-linked debt and longer maturities / Jun I. Kim and Jonathan D.

Ostry.

Other titles: The roles of GDP-linked debt and longer maturities. | IMF departmental paper.

Description: [Washington, DC] : International Monetary Fund, 2017. | Includes bibliographical references.

Identifiers: ISBN 9781484330937 (paper)

Subjects: LCSH: Fiscal policy. | Debts, Public. | Debt Maturity.

Classification: LCC HJ192.5.K548 2017

DISCLAIMER: Departmental Papers showcase policy-related analysis and research being developed by IMF staff members and are published to elicit comments and to encourage debate. The views expressed in this paper are those of the author(s) and do not necessarily represent the views of the IMF, its Executive Board, or IMF management.

JEL Classification Numbers: H62, H63

Keywords: $\quad$ Fiscal space, GDP-linked debt, Debt maturity

Authors’ email addresses: JKim2@imf.org; Jostry@imf.org

\footnotetext{
${ }^{1}$ The authors thank Eduardo Borensztein, Maury Obstfeld, and Tom Sargent for helpful comments on a previous draft, as well as participants at a Bank of England seminar.

${ }^{2}$ Corresponding author: Jonathan D. Ostry, Research Department, IMF, Washington, DC 20431.
} 


\section{Contents}

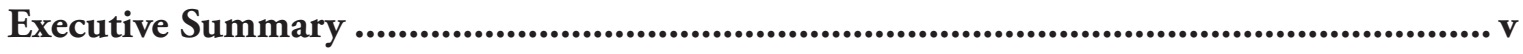

1. Introduction ............................................................................................................................ 1

2. Some Relevant Literature..................................................................................................5

3. Expanding Fiscal Space with GDP-Linked Debt.............................................................9

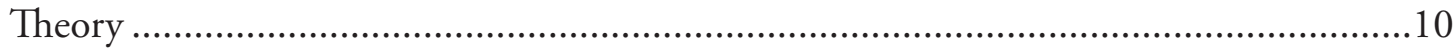

Simulations ...................................................................................................

4. Expanding Fiscal Space with Long-maturity Debt........................................................17

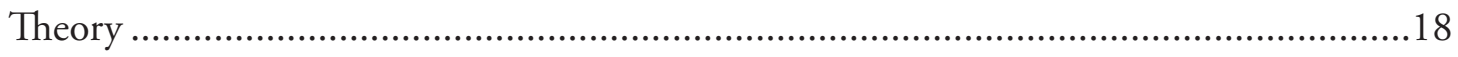

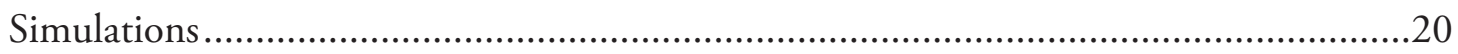

5. Sensitivity to Underlying Assumptions ......................................................................23

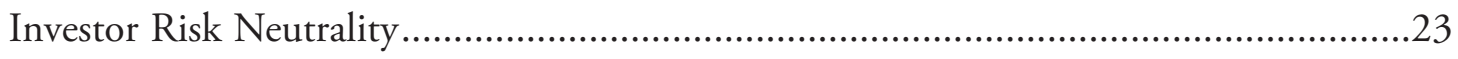

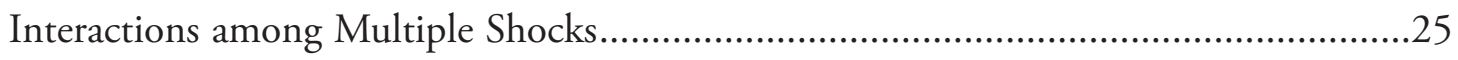

Debt Composition and Marginal Gains in Fiscal Space.................................................26

6. Conclusion ..........................................................................................................................29

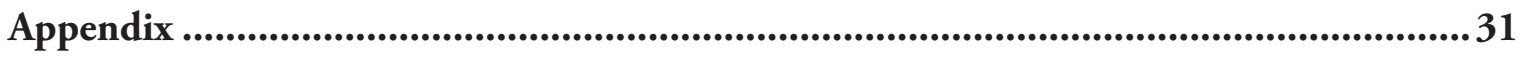

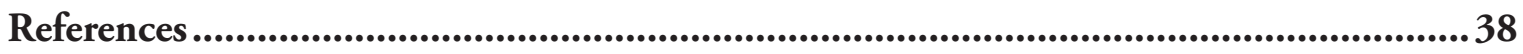

Boxes

1. Calibrating Growth Uncertainty............................................................................15

Figures

1. Debt Limit under Uncertainty: Nominal and GDP-linked Bonds .............................11

B1. Probability Distribution of the Growth Rate: 1980-2020 ……………………......15

2. Debt Limit under Uncertainty: One-period and Long-duration Bonds.......................20

\section{Tables}

1. Debt Limits: Nominal and GDP-linked Bonds....................................................16

2. Debt Limits: Long-duration Nominal Bonds and GDP-linked Bond ........................21

3. Maximum Risk Premiums and Sharpe Ratios: GDP-linked Bond...............................25

4. Effects of Cyclical Fiscal Policy on Fiscal Space ………...........................................26

5. Marginal Gains in Fiscal Space and the Share of GLBs ...........................................27 



\section{Executive Summary}

Fears about secular stagnation have given greater prominence to the use of fiscal tools to support economic growth, especially given the diminishing returns from monetary easing. But the aftermath of the global financial crisis has left many advanced economies with very high sovereign debt ratios, and, likewise, some emerging markets with worrisomely high debt. This has led to caution in using the fiscal instrument even to address well-recognized infrastructural bottlenecks, despite the opportunity afforded by record low interest rates. Against this backdrop, this paper asks whether there are ways to expand fiscal space that do not involve either paying down the debt today or promising to do so in the future (which markets might take cum grano salis). Put differently, are there ways to make fiscal consolidation, if needed, more growth friendly?

We argue that debt management policies may provide an answer, that is a way to expand fiscal space for a given path of primary fiscal balances. Such policies would operate by reducing the risk that a sovereign may default in bad states and, as such, would generate a payoff in terms of reduced real borrowing costs (a tangible benefit for all segments of the IMF's membershipadvanced, emerging, and developing). We explore two debt management policies: issuance of GDP-linked debt and issuance of longer-maturity bonds, as opposed to short-term debt. Such policies, it turns out, can have a powerful effect on fiscal space (defined in this paper as the distance between the current public debt ratio and the debt limit where the sovereign is shut out of the debt market).

The mechanism in play arises because sovereign debt/GDP ratios are buffeted by random shocks to GDP. An assessment of sovereign creditworthiness takes a hit in bad states (recessions) because the probability that the government 
will be unable to service its debt rises in such states. GDP-linked debt contracts can reduce the variability in debt ratios by aligning debt service to the sovereign's ability to pay and reducing the risk of default, allowing debt contracts to be struck at a lower average interest rate, and boosting fiscal space.

Longer maturities also exert a favorable effect on fiscal space. The reason is that the pricing of longer-maturity debt confers a risk-sharing benefit to the issuer, much as equity does, reducing the default premium. Along with other features of longer duration, a lengthening of maturities will act to reduce default risk, lower average borrowing costs, and enhance fiscal space.

Our simulation results suggest that, by managing debt along these two dimensions, gains in fiscal space on the order of 5-40 percent of GDP are plausible taking account of a reasonable allowance for investor risk aversion (and 10-60 percent under the assumption of investor risk neutrality), depending on the extent of growth uncertainty and the cyclicality of fiscal policy. Results also suggest that the scope for gain to the issuer is larger when GDP-linked bonds account for only a negligible share of debt as at present, and that mutual gains for issuers and investors alike should be feasible unless the latter are exceptionally risk-averse or constrained in risk diversification opportunities. 


\section{Chapter}

\section{1 introduction}

Fears about secular stagnation and a prolonged deficiency of aggregate demand in an environment where monetary policy has hit diminishing returns have put a premium on fiscal expansion to stimulate economic growth. But the aftermath of the global financial crisis has left many advanced economies with very high sovereign debt ratios, and even a number of emerging markets with worrisomely high debt. This has led some policymakers to argue that their fiscal space is limited, and thus that it would be difficult to take advantage of the opportunity afforded by low real interest rates to undertake fiscal expansion. They see a fiscal push as unduly raising the risk that markets would penalize them with rising borrowing costs that reflect an increased default risk. They have in mind a fiscal danger zone where the debt ratio gets close to the debt limit (fiscal space is limited); that is, where debt service capacity becomes much harder without an extraordinary fiscal effort.

Concerns about limits to fiscal space at the present juncture raise the issue of how to make what is scarce more plentiful. The obvious way to raise fiscal space is to have a fiscal contraction and pay down the debt. But this runs counter to the goal of using fiscal policy to boost demand. Another way is to promise to pay down the debt tomorrow through forward commitments. But markets might take such commitments cum grano salis.

Is there a way to increase fiscal space that does not require contractionary fiscal policy either today or tomorrow? Alternatively, if fiscal consolidation is deemed necessary for financial-stability reasons, is there a way to make it more growth-friendly — producing larger gains in fiscal space for a given path of consolidation? One way involves reducing the risk that the sovereign might default for a given path of primary fiscal balances. Lower default risk would generate a payoff in terms of reduced real debt service costs, buttressing fiscal space (a tangible benefit for all segments of the IMF's membership—advanced, emerging, and developing). This paper explores 
the role of two debt management policies: issuance of state-contingent debt, and specifically GDP-linked debt; and issuance of longer-maturity debt, as opposed to short-term debt. We abstract from monetary considerations and the possible role of monetary policy in affecting the path of nominal risk-free interest rates; we focus instead on the effect of these debt management policies on real borrowing costs and default risk for the sovereign. Such policies, it turns out, can have a powerful effect on fiscal space, and thus would seem to be salient in the current policy debate.

But how could debt management policies actually yield the benefits we are claiming without the need for current or future fiscal effort? Surely such a "free lunch" is implausible, and the only genuine way to allow a government to borrow more cheaply is for it to lower its debt, either now or (credibly) in the future, which would mean that we are back to square one.

The mechanism we have in mind arises because the evolution of sovereign debt ratios depends on the evolution of GDP, which is buffeted by random shocks. In bad states (e.g., a financial crisis, earthquake, or downturn in a key trading partner), sovereign debt ratios are pushed up because their denominator, GDP, is pushed down. An assessment of sovereign creditworthiness takes a hit because the higher debt ratio increases the chance that the government will not be able to service its debt (reflecting the hit to the sovereign's "ability to pay" arising from weaker revenues and primary balances). If the debt contract were instead written to give the sovereign a break on its debt service cost during such bad times (in exchange-to keep the lender's expected profit the same-for an increased interest rate during a boom), default risk would decline; this would allow the debt contract to be written with a lower average interest rate (reflecting the lower probability of default).

Another way of saying the same thing is to note that if the interest rate is linked to GDP, the debt limit will be increased because the set of states in which the sovereign will be unable to service its debt without an extraordinary effort will be more limited than when the debt contract is in nominal terms - this is indeed the very definition of expanded fiscal space. Yet a third way to understand the mechanism at play is to recognize that the interest rate is a convex function of the debt ratio because, as debt rises toward the debt limit, investors will demand a higher interest rate to compensate for greater default risk, but this will further raise default risk and the interest rate. The average interest rate on nominal debt thus will be increasing in the extent of growth uncertainty. A GDP-linked debt contract which reduces the variability in the debt ratio can be struck therefore at a lower average interest rate while maintaining the lender's same expected profit.

What about maturity of the debt? Logic suggests that longer maturities can also have a favorable effect on fiscal space. The reason is that the pricing of 
longer-maturity debt confers a risk-sharing benefit to the issuer, much as equity does, reducing the default premium. The price of longer-maturity debt depends on the expected value of future prices. In good future states, the price of debt rises with the growth rate, and part of this gets translated into higher debt prices today. In bad future states-sufficiently bad so that default occurs - the price of debt drops to zero irrespective of the growth rate, and investors recover only a predetermined amount. This implies effectively that the impact of bad future states on debt prices and yields gets censored. This mechanism - through which favorable shocks underpin the market value of debt whereas unfavorable shocks do not have an offsetting impact-implies that both bond prices and debt ratios will be more stable in the case of long-term debt than short-term debt. Along with other features of longer duration, a lengthening of maturities will act to reduce default risk, lower average borrowing costs, and enhance fiscal space.

We develop these points analytically in what follows, and undertake numerical simulations in order to gauge their practical significance. Our results suggest that, by managing debt along these two dimensions, gains in fiscal space on the order of 5-40 percent of GDP are plausible taking account of a reasonable allowance for investor risk aversion (and 10-60 percent if investors are risk neutral). These gains arise because of the reduction in default risk made possible by debt management policy along the two above dimensions. The simulations also shed light on the extent of the risk premium that issuers would be willing to pay as compensation to investors.

In Chapter 2, we review the literature on GDP-linked debt and maturity structure, and discuss how our analysis fills some gaps in this literature. In Chapters 3 and 4, we discuss how uncertainty affects fiscal space and how debt management can play a role in increasing fiscal space, and provide estimates of potential gains in fiscal space flowing from debt management. Chapter 5 discusses the sensitivity of the findings to some underlying assumptions, and draws a number of policy implications. Chapter 6 concludes. 



\section{Chapter}

\section{Some Relevant Literature}

GDP-linked bonds (GLBs) have long been seen as offering potential benefits for both issuers and investors. By linking payments on sovereign debt to the issuing country's GDP, GLBs can help stabilize debt ratios and reduce vulnerability to external shocks and financial crises. ${ }^{1}$ Using ad hoc simulation methodologies, Borensztein and Mauro (2004) and Blanchard et al. (2016) show the debt-stabilizing effects of GLBs; using similar methods, Barr et al. (2014) and Bank of England (2016) assess that GLBs can significantly increase debt limits and reduce default risk. Council of Economic Advisers (2004) argues that issuing debt in GLBs would facilitate countercyclical fiscal policy, an especially valuable contribution in the case of emerging market economies. For investors, GLBs may further enhance return and diversification opportunities across a broad range of countries.

Several recent studies have investigated the welfare implications of GDP-linked debt within an optimizing framework, and concluded that GDP-linked debt can raise national welfare. Durdu (2009) studies the effects of one-period income-indexed debt on consumption and welfare, but abstracts from endogenous default risk, a key channel in the framework developed in this paper. Hatchondo and Martinez (2012) introduce income-indexed bonds into a model of strategic sovereign default and find that welfare gains may be significant. Onder (2016) shows how welfare gains from issuing GDP-linked debt depend on the nature of the indexation scheme for the debt.

\footnotetext{
${ }^{1}$ For an early contribution on the benefits of GDP-linked securities, see Shiller (1993). Obstfeld and Peri (1998) propose the issuance of perpetual GDP-linked securities by national governments in the European Monetary Union as an alternative to direct fiscal transfers under the European Transfer Union. In a similar vein, Drèze (2000) suggests the issuance of perpetual GDP-linked bonds to facilitate international macro-risk sharing.
} 
Notwithstanding the potential benefits, GLBs have rarely been issued by emerging market economies outside a sovereign debt restructuring context (Griffith-Jones and Sharma 2005). Obstacles relate inter alia to potential misreporting of GDP data by issuers and difficulties in ex post verification of the data, and complications from ex post GDP revisions and methodological changes. GLBs are viewed by investors as risky and insufficiently liquid, though recent work has argued that demand for GLBs might be substantial from defined-benefit pension funds because of the risk characteristics of these instruments (with yields closely correlated with GDP, much like the liabilities of the pension funds themselves-Borensztein 2016). Issuers are concerned with extra premiums that they may have to pay to compensate investors for illiquidity, novelty, and return volatility.

With respect to pricing difficulties, investors may be concerned about the analytical complexity involved in estimating the "theoretical price" of GLBs (Borensztein et al. 2004) but the literature to date has not provided much guidance. Chamon and Mauro (2006) propose a pricing method for GLBs based on a simple debt sustainability framework, but their results depend crucially on ad hoc assumptions that the default probability is constant and the same for both nominal and GDP-linked bonds even in the presence of growth uncertainty. Kruse et al. (2005) and Miyajima (2006) provide pricing frameworks for GDP-linked financial products based on Black-Scholes or present-value models, but they too abstract from sovereign default risk.

Regarding debt duration, early studies examined optimal maturity structure in the context of achieving socially desirable tax smoothing or addressing debtor moral hazard. ${ }^{2}$ More recent studies focus on trade-offs between rollover risks and borrowing costs. Broner et al. (2013) highlight the trade-off between safer longer-term debt and cheaper short-term debt, and present evidence that emerging market economies pay a positive term premium, with issuances shifting toward shorter maturities during crises in the face of steep increases in the term premium. Greenwood et al. (2015) focus on comparative advantages of different maturities in terms of rollover risk and liquiditybut abstract from default risk. Arellano and Ramanarayanan (2012) develop a dynamic optimizing model to account for observed patterns in the term structure of spreads and debt issuance by emerging markets. In their model, longer maturities provide a hedge against volatility in spreads whereas short-maturities are less vulnerable to borrower disincentives to repay.

\footnotetext{
${ }^{2}$ Barro (1995) argues for issuing debt as a perpetuity to achieve desirable tax-smoothing properties. Angeletos (2002) shows that an optimal maturity structure under uncertainty involves long-maturity debt, and that a sufficiently rich maturity structure can replicate the resource allocation that would emerge if a complete set of Arrow-Debreu (state-contingent) securities were available. For a discussion of debt maturity in the presence of debtor moral hazard, see Missale and Blanchard (1994) and Jeanne (2009).
} 
The existing literature argues that GDP-linked debt can help stabilize debt ratios and reduce default risk under growth uncertainty, but does not provide an analytical framework to rigorously establish these results nor to ground the quantification of gains in fiscal space as a function of underlying uncertainty. The literature also has not made much progress in establishing the theoretical price of GLBs in a coherent framework that incorporates sovereign default risk-surely the relevant case. Beyond the role of growth-linked instruments, the impact of debt maturities on fiscal space has been underexplored in the relevant case of frameworks that incorporate sovereign default risk. Our analysis attempts to fill these gaps in the literature by developing an analytical framework to determine the debt limit and theoretical prices of GDP-linked and long-maturity debt under uncertainty and in the presence of default risk. The quantified gains in fiscal space flowing from debt management policiesobtained from simulations grounded in the underlying model—will in our view be more reliable than many of the ad hoc approaches that are typical in the existing literature. 



\section{Chapter}

\section{Expanding Fiscal Space with GDP-Linked Debt}

We develop a framework to determine a country's debt limit- the level beyond which fiscal solvency is in doubt-and its fiscal space defined as the difference between current debt and the debt limit. ${ }^{1}$ It is helpful to think of the sovereign's behavior as summarized by a reaction function linking the primary balance to debt and other factors, and to view atomistic creditors as setting lending rates that reflect the risk that the borrower may be unable to pay and thus defaults. We assume that governments behave responsibly in the sense that, as long as debt is not too high (as discussed below), they increase their primary balance in response to rising debt to ensure that the debt ratio converges to some reasonable value-this is indeed the empirically relevant case for most advanced economies: see Bohn (2008) and Mendoza and Ostry (2008). However, there are economic and political limits to how high primary balances can rise, which means that fiscal responsibility, defined in terms of the extent of the response to rising debt, cannot hold for all debt levels. ${ }^{2}$ Beyond some point, a further increase in debt is unlikely to elicit a fiscal response sufficient to offset the rising interest bill (the primary balance cannot exceed GDP, and is infrequently more than a few percentage points of GDP). Ostry et al. (2010) develop the concept of fiscal fatigue to account for this and document its relevance empirically.

\footnotetext{
${ }^{1}$ Fiscal space is a multidimensional, forward-looking concept. As such, an assessment of fiscal space requires a consistent set of considerations over a number of factors (e.g., economic conditions, market access, present and future financing needs, liquidity and solvency of the fiscal position under alternative scenarios, etc.), and various approaches have been used to assess fiscal space (IMF 2016). Fiscal space as defined in this paper is thus a narrower concept than has been used by the IMF in its surveillance work.

${ }^{2}$ Abiad and Ostry (2005) discuss different concepts of maximum primary balances, in relation to the country's historical track record during normal times, periods of extraordinary fiscal effort, the extraordinary effort of regional or world peers, and the presence of external anchor institutions such as the IMF or the European Union.
} 
The notion of fiscal fatigue directly underpins the existence of a debt limit and the idea of fiscal space. If the primary balance eventually cannot keep up with rising debt service as debt rises (the increment to the primary balance ratio is smaller than the interest-rate-growth differential), there will be some debt level above which the debt dynamics become explosive. This is the case even if, counterfactually, lenders continue to lend at the risk-free rate up to the debt limit, which of course they will not do once default risk emerges. Rising default risk and interest rates feed on one another: the former raises the interest rate and the latter raises default risk. This loop eventually comes to an end at a "fixed-point," which yields a finite interest rate consistent with underlying default risk. The highest debt level that can be serviced at a finite interest rate is the debt limit, and the distance between current debt and this limit defines fiscal space. If shocks were to push debt above its limit, debt dynamics would become explosive, and the country would no longer be able to borrow at a finite interest rate-i.e., it would be shut out of the capital markets and be forced to default.

\section{Theory}

The model used to establish the debt limit follows Ostry et al. (2010). To understand how growth uncertainty affects the debt limit and fiscal space, it is useful to begin with the case where growth is certain-i.e., the GDP growth rate is constant at some rate, $g^{*}$. To start, the sovereign is assumed to have available to it only non-state-contingent bonds. It enjoys market access (i.e., it can borrow at a finite interest rate), and so the change in its debt ratio from one period to the next will be governed by the difference between the debt service obligation and the primary balance, as stipulated in the standard budget constraint:

$$
d_{t+1}-d_{t}=\left[\left(r_{t}-g_{t+1}\right) /\left(1+g_{t+1}\right)\right] d_{t}-s^{*}
$$

where $d$ refers to the debt-to-GDP ratio, $r$ is the interest rate charged on the debt (or the bond yield), $g$ is the GDP growth rate, and $s^{*}$ is the primary balance as a share of GDP. Now consider some adverse shock that pushes the sovereign's debt ratio above its debt limit so that it loses market access because of its inability to pay (the second term on the right-hand side of equation (1) is less than the first term even when the interest rate remains at the risk-free rate). The probability of default is unity in such a case and the interest rate is no longer finite (the sovereign is shut out of the bond market). This simple thought experiment shows that the debt limit is determined where the primary balance and debt service obligation just offset each other, 


\section{Figure 1. Debt Limit under Uncertainty: Nominal and GDP-linked Bonds}

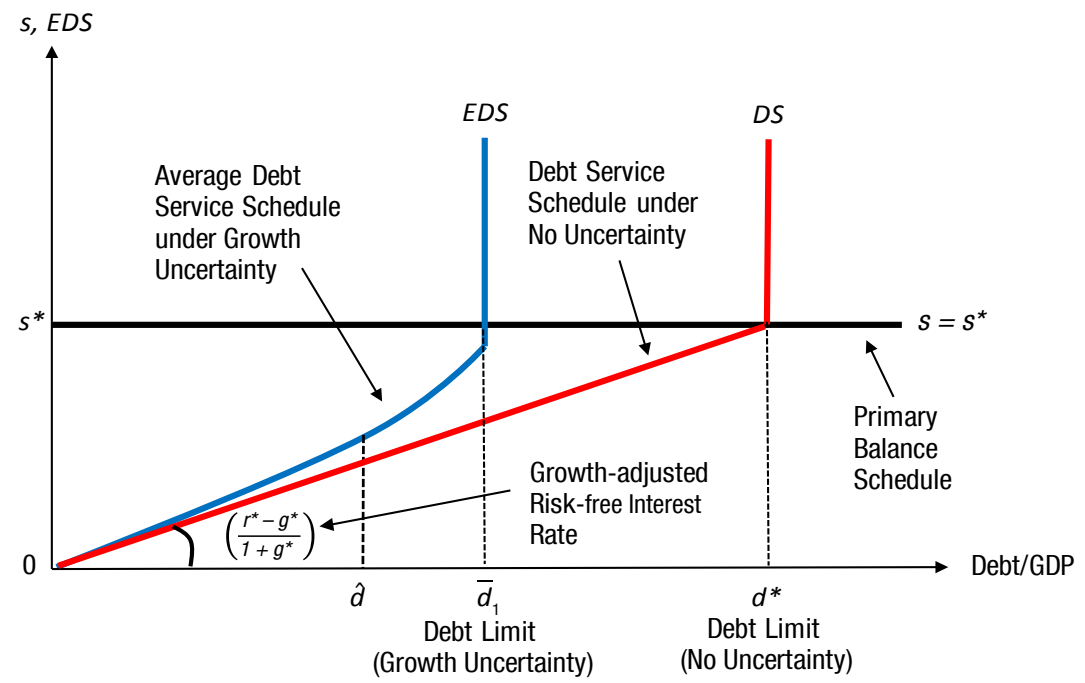

as shown by the intersection of the black primary balance schedule and the red debt service schedule in Figure $1 .{ }^{3}$

Now consider the case where GDP growth is uncertain. Specifically, the next period's growth rate is random and varies over some finite range, with the average equal to $g^{*}$ as before. How, given that debt service obligations depend on the unknown future growth rate, can we establish the debt limit? To answer the question, it pays to consider the default decision of the sovereign, which holds that default occurs whenever the debt ratio (which depends on the random growth rate) exceeds the debt limit (and not otherwise-there is no "strategic" default). The probability of default is the risk that this happens: it is therefore the risk that growth is below some threshold, or equivalently (since growth is the only source of uncertainty in the model), the risk that the debt ratio is above some threshold. It is obvious that this probability implicitly defines the debt limit - which is nothing other than the debt ratio above which default is certain.

As progressively more adverse draws are realized from the growth distribution, default becomes more probable because the resources needed to fulfill debt service are fixed by the debt contract, but the capacity to meet them

\footnotetext{
${ }^{3}$ To simplify the theoretical exposition, we assume in this chapter that the primary balance as a share of GDP is constant (perhaps at some level that corresponds to the maximum primary balance in our earlier model of fiscal fatigue). In the simulations undertaken later in this paper, we consider the general case where the primary balance follows a fiscal reaction function and is subject to shocks.
} 
from primary balance resources diminishes, raising the odds of a shortfall. ${ }^{4}$ This greater risk gets reflected in the bond price or yield (which depends on the default probability), making the challenge of meeting the debt service obligation even greater. At low debt levels, the likelihood of growth draws that will force default is small, while at more elevated debt levels the probability of default is higher. Indeed, if debt is so low that the worst possible growth draw necessarily leaves the lender whole, the borrower will contract at the risk-free rate; while if debt is very high so that the best possible draw from the growth distribution would still not yield enough primary balance resources to service the debt, then default will be certain, and the bond price will fall to zero (or, equivalently, the bond yield becomes infinite). In between, yields will rise at an increasing rate with debt once default risk emerges (once debt is no longer low enough to guarantee full repayment under the worst possible growth draw).

In the appendix, we establish formally that the debt limit, denoted by $\bar{d}$, solves the fixed-point problem defined in the expression for the default probability:

$$
p_{t+1}=\operatorname{Pr}\left[d_{t+1}>\bar{d}\right]
$$

where $p_{t+1}$ is the probability of default, i.e., the probability that debt exceeds the debt limit. That this constitutes a fixed-point problem reflects the dependence of the default probability on the bond price or the yield, and the dependence of the price or yield on the default probability. The appendix establishes that there is a specific minimum or threshold growth outcome below which this fixed-point problem has no interior solution or equivalently a maximum threshold debt ratio above which this fixed-point problem has no interior solution. This is the debt limit. For debt ratios below the debt limit, the sovereign borrows at a finite interest rate, while if a shock pushes the debt ratio above the limit, the fixed-point problem no longer has an interior solution (with a default probability strictly less than unity), and the sovereign must default because it can no longer borrow at a finite interest rate. If the debt ratio in the current period is exactly equal to the debt limit, three outcomes are possible in the next period depending on the realized growth rate. The primary balance may either (1) just suffice to meet the debt service obligation - this will be the case if the actual growth outturn equals the threshold rate (the debt ratio in this instance will be constant from one period to the next, and equal to the debt limit, and default will

\footnotetext{
${ }^{4}$ In proportion to GDP, it is the other way around: the primary balance is fixed but the resources needed to fulfill the debt contract are falling with GDP (reduced GDP implying a greater debt service obligation as a ratio to GDP).
} 
be avoided) — or (2) be more than enough, in which case default is again avoided and the debt ratio will decline-or (3) be insufficient—in which case the sovereign must default, and the bond price drops to zero because lenders will find that the debt ratio will increase without bound, and thus they will not lend.

We can use the diagrammatic apparatus in Figure 1 to illustrate the uncertainty case and how it compares to the certainty case discussed earlier. The blue line portrays the expected debt service (EDS) schedule, where the expectation is taken with respect to the random growth rate. The salient feature of the blue line (which is convex in the growth rate) is that it must lie above the red line. Moreover, it bends upward (and becomes convex-i.e., increases with debt at an increasing rate) at higher debt levels above $\hat{d}$ as default risk emerges, causing the bond yield to rise above the risk-free interest rate. The blue line becomes vertical once debt exceeds the debt limit as the bond yield becomes infinite given the unit default probability. Because of the convexity of the bond yield, the debt limit in the uncertainty case, denoted by $\bar{d}_{1}$, is reached earlier than in the absence of growth uncertainty, and thus lies to the left of $d^{*}$, the debt limit in the certainty case.

In summary, growth uncertainty lowers the debt limit and reduces fiscal space. This reflects the fact that bond yields are convex with respect to the default risk, and that default risk is itself increasing in the debt ratio. This implies that the unit cost of borrowing is convex with respect to the debt ratio. The higher average cost of borrowing under uncertainty reflects the fact that the lender gets no upside from a good shock, but it must absorb the downside from a bad shock in the case of default. To achieve the same expected return as under certainty, the average cost of borrowing will need to be higher. Moreover, as the extent of uncertainty increases, the blue line in Figure 1 will rotate counterclockwise, and bend upward earlier and more steeply. In consequence, the debt limit will be reached at an even lower debt level-more so, the larger the growth uncertainty.

It is now possible to explore how the introduction of GDP-linked debt into the sovereign's financing options affects the picture. Suppose that the sovereign issues bonds whose payout at maturity $(\rho)$ is tied to the growth outcome:

$$
\rho_{t+1}=\left(1+g_{t+1}\right) /\left(1+g^{*}\right)
$$

It is clear that, under this setup, the GDP-linked bond completely insulates the issuer from the impact of growth uncertainty, since the payout varies in proportion to the growth outcome-giving a break to the issuer in bad times 
in exchange for a higher payout in good times, the expected value of which is equal to the payout of the nominal bond (which ensures that the lender gets the same expected return as with the nominal bond). The GDP-linked instrument acts as a perfect risk-sharing device: giving the issuer a reduced obligation when its capacity to generate resources for debt service suffers, in exchange for a higher obligation when its capacity to pay is greater. In fact, as shown in the appendix, this risk-sharing property of the GDP-linked instrument returns us to the world of perfect certainty, moving the debt service schedule back to the red line in Figure 1, and restoring fiscal space to the level that prevailed when there was no uncertainty.

Would the lender be willing to acquire such a security? A risk-neutral one surely would as her expected receipts are independent of the extent of uncertainty; if the creditor is risk averse, she would need some compensation for absorbing the additional risk, an issue we discuss below (but note that the debtor is strictly better off if defaults are costly and fiscal flexibility is of value - and thus should be willing to pay some premium to issue GDP-linked securities).

An important advantage of having more fiscal space is that it leaves the country in a position where positive and negative shocks have closer to symmetric effects on the debt ratio over a wider range of debt. As discussed earlier, positive and negative shocks to the growth rate have asymmetric effects on the debt ratio whenever default risk is present or, equivalently, whenever the debt service schedule is convex with respect to the debt ratio. The higher debt limit engendered by GLBs implies that the convex segment of the debt service schedule will emerge at a higher debt ratio than is the case for nominal bonds. This implies that, in any given period, the debt ratio will exhibit less dispersion if GLBs are issued rather than for nominal bonds. This prediction is well confirmed by the simulation results reported for example by Blanchard et al. (2016) and Benford et al. (2016).

\section{Simulations}

To determine the plausible size of gains in fiscal space from the introduction of GLBs, we simulate the model for a representative advanced economy. We assume that the primary balance ratio is no longer constant but stochastic, and also follows a cubic fiscal reaction as in Ostry et al. (2010)—estimated from data for a sample of advanced economies - in order to allow for fiscal fatigue according to which fiscal effort peters out at relatively high debt ratios. ${ }^{5}$ The shock to the primary balance, $e_{t+1}$, is independently and iden-

\footnotetext{
${ }^{5}$ Specifically, $s_{t+1}=f\left(d_{t}\right)+e_{t+1}$ where $f(d)$ is a cubic function. The intercept term of $f(d)$ captures the effect of all determinants of the primary balance other than the lagged debt ratio. In the simulation, it is set to 1.15 percent of GDP, which corresponds to the cross-country median of country-specific intercepts.
} 


\section{Box 1. Calibrating Growth Uncertainty}

This box summarizes how growth uncertainty is calibrated in the simulations. The growth rate is assumed to be distributed over $n$ discrete values, $\left\{g_{j}\right\}_{j=1}^{n}$, with associated probabilities, $\left\{\pi_{j}\right\}_{j=1}^{n}$, where $-1<g_{j}<g_{k}<\infty$ for $j<k$. Given this assumption, the distribution of the growth rate is calibrated by using the sample histograms (constructed for 25 bins; $n=25$ ) of the real GDP growth rate of 23 advanced economies (covered by Ostry et al. (2010)) over 1980-2020 (where the projected data for 2016 onward is taken from the IMF's World Economic Outlook). Panel 1 below displays the histogram of cross-country average growth rates over 1980-2020: the mean is 2.4 percent while the standard deviation is 1.4 percent. Panel 2 shows the histogram of the pooled data of individual countries' growth rates: the mean is the same as before obviously but the standard deviation is much larger ( 2.5 percent). In the simulation, the histogram in panel 1 is used for the low-uncertainty case while the one in panel 2 is used for the high-uncertainty case.

Figure B1. Probability Distribution of the Growth Rate: 1980-2020
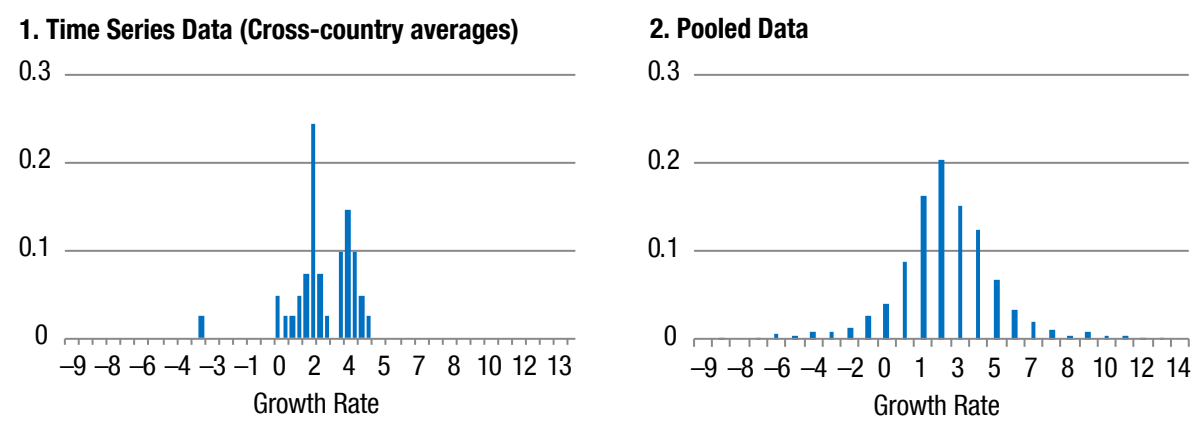

tically distributed and is assumed to follow a triangular distribution over a finite support $[-2.16,2.16]$ — the notion being that, in practice, primary balances are observed to lie in a narrow range. The selected value of the support (measured in percent of GDP) is large enough to capture the extent of observed deteriorations in primary balances in recessions. ${ }^{6}$

The distribution for the GDP growth rates is calibrated by using the sample histograms using annual data for 23 advanced economies over the period 1980-2020 (including IMF World Economic Outlook forecasts)—see Box 1. The risk-free interest rate $r^{*}$ is set to equal 1.1 percent, which is the average of the US Treasury and German Bund yields for 1, 5, and 10-year matur-

\footnotetext{
${ }^{6}$ The chosen end points of the support represent the median of the country-specific averages of the worst five residuals from the estimation of the $f(d)$ fiscal reaction function.
} 
Table 1. Debt Limits: Nominal and GDP-linked Bonds

\begin{tabular}{|c|c|c|c|}
\hline \multirow[b]{2}{*}{ Growth Uncertainty } & \multicolumn{2}{|c|}{ Debt Limit } & \multirow[b]{2}{*}{$\mathbf{B}-\mathbf{A}$} \\
\hline & Nominal Bond (A) & GDP-linked Bond (B) & \\
\hline Low & 179.7 & 199.4 & 19.7 \\
\hline High & 159.1 & 199.4 & 40.3 \\
\hline
\end{tabular}

Source: Authors' calculations.

Note: Debt limits are in percent of GDP.

ities (adjusted for GDP deflator inflation) over 2000-15. A recovery value of 90 percent on defaulted debt is assumed-consistent with the estimates reported by Benjamin and Wright (2009) for upper-middle-income countries-but we discuss below how results would be affected under more pessimistic assumptions about recovery rates in default.

Table 1 reports simulated debt limits for nominal and GDP-linked bonds. For the nominal bond, the debt limit is affected by the extent of growth uncertainty: it is about 180 percent of GDP in the case of low growth uncertainty, and falls to 159 percent for the high-uncertainty case. For the GDP-linked bond, the debt limit is unaffected by the extent of growth uncertainty. Gains in fiscal space resulting from GDP-linked debt as shown in the last column are some 20 percent of GDP when uncertainty is low and 40 percent in the case of high uncertainty.

Simulated gains in fiscal space would differ depending on model parameters and assumptions. A lower recovery rate, for example, leads to a lower debt limit for both nominal bonds and GLBs. This is because investors will lose more upon default and hence charge a higher interest rate for a given default probability. A higher borrowing cost then leads to a lower debt limit. As the recovery rate falls, however, the debt limit declines by more for nominal bonds than for GLBs, because the default risk (and hence the expected loss from default) is greater for the former, resulting in a larger increase in the borrowing cost. This in turn implies that potential gains in fiscal space from issuing GLBs would be larger the lower the recovery rate. In our model, for instance, simulated gains in fiscal space almost double even in the case of low uncertainty - from about 20 percent of GDP to 36 percent of GDP - if the recovery rate is reduced from 90 percent to 70 percent. Finally, it bears emphasizing that the quantitative results are not meant to provide normative guidance for desirable debt levels; in particular, there is no implication that fiscal space should be targeted toward zero, not least because systematically exploiting fiscal space would induce an endogenous response of borrowing yields, and because countries will want to steer well clear of their debt limits (the tipping point for debt sustainability, and thus not an indicator of a safe debt level) because markets can react very quickly to shocks, with yields rising abruptly from their risk-free levels (Ostry et al. 2010). 


\section{Chapter}

\section{Expanding Fiscal Space with}

It has long been recognized that a lengthening of debt maturities can help give the sovereign room for maneuver, reducing rollover risk. With longer maturities for example, debt service is more evenly spread out (the gross financing need-GFN—will generally be smaller than the outstanding debt stock), reducing the vulnerability of debt dynamics to adverse shocks either to growth or the primary balance. There is also a well-known hedging benefit from long-term debt: when interest rates rise, debt service costs for newly issued debt rise, adding to the variability in the debt ratio, but the market value of outstanding debt falls, reducing the variability in the debt ratio. The first effect is present for both short- and long-term debt, while the second effect is a net advantage of longer maturities that serves to reduce stochastic variation in the debt ratio.

We argue in this chapter that there is an additional risk-sharing benefit from longer-duration debt-not previously established in the literature-that allows the sovereign to enjoy beneficial transfers of risk across states and time, and it operates through the price of long-term debt. In the case of a long-term instrument (i.e., one whose duration is longer than one period), today's price depends not only on the distribution of growth outcomes in the next period, but also on the price of the bond that is expected to prevail in the next period, because that price summarizes all the information relevant to investors about future shocks that could impact debt servicing capacity and default risk over the lifetime of the bond. The dependence of the current price on the expected future price, which is absent in the case of short-term debt, implies that the price of long-term debt will be more resilient to adverse shocks to GDP growth or fiscal balances.

The interesting thing about the expected future price is that it incorporates all the value from the bond as long as the sovereign is not in default. In states bad enough to induce default, the bond has no value other than the prede- 
termined recovery value. This induces an asymmetry. Good shocks are fully factored into the bond's expected future price (with future prices increasing for better shocks), but the impact of shocks that are bad enough to result in default gets censored. Another way to look at this is to recall that following a bad shock, there is always the possibility of a compensating good future shock if the bond survives. This redemption possibility adds value to the long-term bond (but not the short-term bond), underpinning its price, reducing the risk premium and serving to stabilize the debt ratio. This gives the long-term instrument an equity-like, risk-sharing character.

\section{Theory}

To formalize the argument, we extend the model by introducing a long-duration bond for which coupon payments decay geometrically at the rate $\delta$ over time (see appendix). ${ }^{1}$ In any period, the sovereign will have to meet coupon obligations on all vintages of past debt, while the resources available to it will come from newly issued debt and the primary balance, as indicated in the standard debt dynamics equation:

$$
x_{t+1}=\left(x_{t} / q_{t}\right) /\left(1+g_{t+1}\right)+(1-\delta) b_{t} /\left(1+g_{t+1}\right)-s^{*}
$$

where $q$ is the bond price, and $b$ and $x=b-s^{*}$ denote, respectively, aggregate coupon payments and the gross financing need (GFN), both as a share of GDP. Recalling that coupons decay at the rate $\delta$, the first two terms on the right-hand side represent, respectively, debt service obligations on currently and previously issued long-term debt.

A key point is that the equilibrium bond price, which appears in the debt dynamics equation, depends not just on the probability of default one period ahead (as in the simple one-period debt case discussed in the previous section), but on the default risks throughout the entire life of the bond (for which the one-period-ahead expected future price is a sufficient statistic):

$$
\left.q_{t}=\left(1-p_{t+1}\right)\left[1+(1-\delta) q_{t+1}^{E}\right)\right] /\left(1+r^{*}\right)
$$

\footnotetext{
${ }^{1}$ The specification we adopt has been widely used in the literature on sovereign debt: see, for example, Hatchondo and Martinez (2009), Arellano and Ramanarayanan (2012), and Chatterjee and Eyigungor (2012). Although the bond has infinite maturity, our qualitative findings would hold for long-but-finite-maturity debt as well.
} 
where $q_{t+1}^{E}=E_{t}\left[q_{t+1} \mid q_{t+1}>0\right]$ is the expected bond price in the next period in a no-default state. As can be seen from equation (5), the one-period-ahead expected bond price underpins the current price because it weights the probability of favorable future growth shocks but not unfavorable ones that result in default (where coupon payments would be zero). ${ }^{2}$

As before, the debt limit and the price of the long-duration bond are determined by a fixed-point problem for the (one-period-ahead) default probability. There will continue to be a threshold growth rate below which primary balance resources will not suffice to make the coupon payments on all vintages of long-maturity debt. What is different from the short-term debt case is that debt service, and thus the threshold growth rate, depends in part on the expected future value of the bond. Given this dependence, the threshold growth rate will be lower than in the one-period debt case, and the solution to the fixed-point problem (the largest debt ratio for which the problem has an interior solution) will occur at a higher debt ratio- the sovereign has more room because of the expectational term. This means that fiscal space will be larger in the case of the long-duration bond.

Figure 2 illustrates the determination of the debt limit for the long-duration bond under uncertainty. The blue and red solid lines portray, respectively, the (expected) debt service schedule for the one-period bond with and without growth uncertainty. Since debt duration does not matter for the debt limit in the certainty case, the red line also represents the debt service schedule of the long-duration bond in the certainty case. The green line represents the expected debt service schedule for the long-duration bond under growth uncertainty: it overlaps the blue line at sufficiently low debt levels (when there is no default risk) but eventually lies below the blue line if the debt ratio increases further. ${ }^{3}$ What is important is that the debt service requirement increases, on average, more slowly with debt for the long-maturity instrument, given the potential for favorable (debt-service-enhancing) shocks in the future. For a given path of the primary balance, therefore, longer duration enhances fiscal space. The debt limit for the long-duration bond, denoted by $\bar{d}$ in the figure, lies between the debt limit of short-term debt and the debt limit in the certainty case.

\footnotetext{
${ }^{2}$ The expectational term in (5), common in rational expectations models, underscores the existence of multiple equilibrium solutions in this type of model. Multiple equilibria emerge because of the feedback from future to current prices. At a given debt ratio, a higher value of $q_{t+1}^{E}$ increases the current bond price. For any realized GDP growth rate, this will lead to a lower debt ratio and a higher bond price in the next period. As a result, the higher value of $q_{t+1}^{E}$ becomes justified ex post. In what follows, we assume that investors use a common equilibrium selection rule under which the equilibrium price of the long-duration bond is lower the higher the debt ratio.

${ }^{3}$ The green line is drawn under the assumption that expected debt service at the debt limit is less than the primary balance, which is likely to be the case if the threshold growth rate for default is relatively low.
} 
Figure 2. Debt Limit under Uncertainty: One-period and Long-duration Bonds

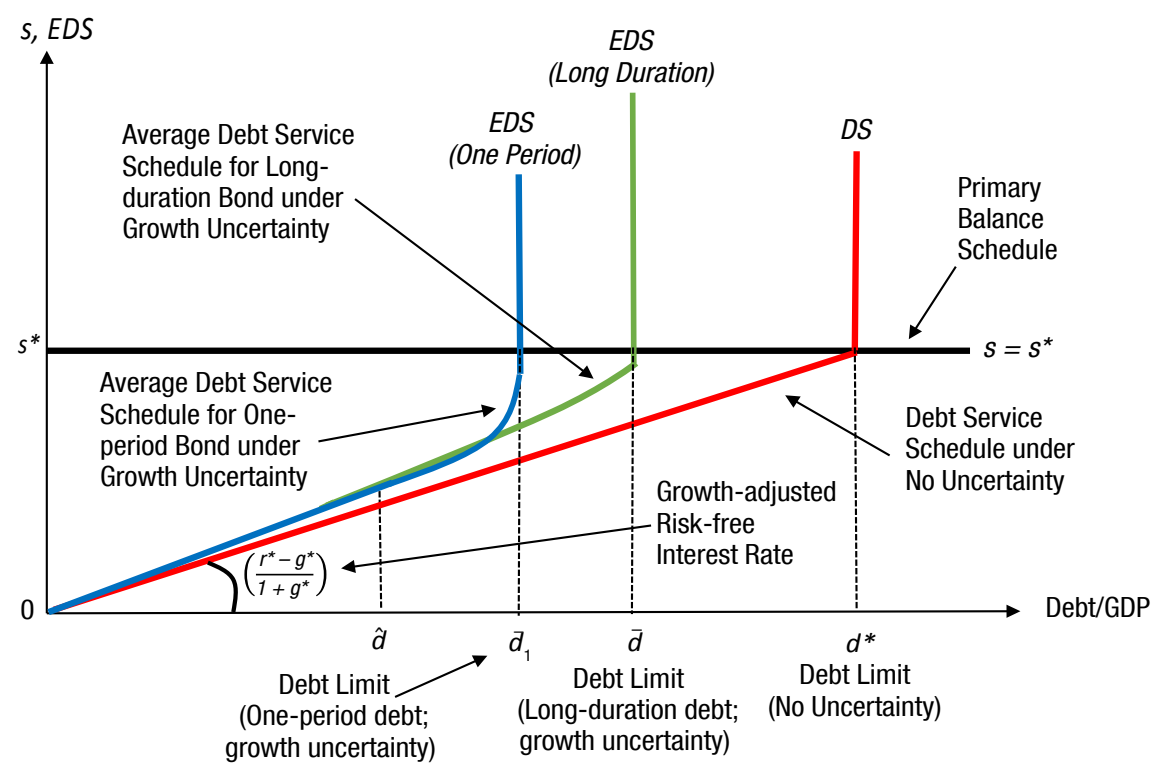

\section{Simulations}

How significant is the impact of debt maturity on fiscal space likely to be? As discussed above, the model of long-duration debt deployed in this chapter has (in common with rational expectations models in many contexts) multiple solutions (indexed by the expectations of future bond prices-more optimistic expectations implying a higher debt limit). To quantify the impact of debt duration on debt limits and fiscal space, we impose some restrictions on the solution that go in the direction of ruling out the most optimistic expectations and correspondingly large debt limits of the longer-duration instruments. ${ }^{4}$ Given the challenges involved in simulating actual debt limits of long-duration debt, we simplify the model by abstracting from primary balance uncertainty and determine some lower bounds for the debt limit (true debt limits, and correspondingly fiscal space, will thus be larger than what is reported in the table below). Reflecting these simplifications, the simulation results here are not directly comparable to those reported in the previous chapter.

Table 2 reports the results for long-duration nominal bonds and, for comparison, the results for the GDP-linked bond as well (under the common set of

\footnotetext{
${ }^{4}$ The appendix provides the details — the gist however is simply that, by ruling out a range of optimistic price expectations, we stack the deck against assessing sizable benefits of debt duration on fiscal space.
} 
Table 2. Debt Limits: Long-duration Nominal Bonds and GDP-linked Bond

\begin{tabular}{|c|c|c|c|c|c|c|c|}
\hline \multirow{2}{*}{$\begin{array}{l}\text { Growth } \\
\text { Uncertainty }\end{array}$} & \multicolumn{3}{|c|}{$\begin{array}{c}\text { Debt Limit of Nominal Bond } \\
\text { (By duration) }\end{array}$} & \multirow{2}{*}{$\begin{array}{l}\text { Debt Limit } \\
\text { of GLB (D) }\end{array}$} & \multirow[b]{2}{*}{$\mathbf{B}-\mathbf{A}$} & \multirow[b]{2}{*}{$\mathbf{C}-\mathbf{A}$} & \multirow[b]{2}{*}{$\mathbf{D}-\mathbf{A}$} \\
\hline & 1 year $(\mathrm{A})$ & 10 years $(B)$ & 20 years $(C)$ & & & & \\
\hline Low & 87.6 & 103.5 & 135.0 & 204.8 & 15.9 & 47.4 & 117.2 \\
\hline High & 65.3 & 104.6 & 137.6 & 204.8 & 39.4 & 72.3 & 139.5 \\
\hline
\end{tabular}

Source: Authors' calculations.

Note: Debt limits in column (A) for one-year duration refer to the actual debt limit of the one-period bond, while those reported in columns (B) and (C) are a lower bound of the actual debt limit for the longer-duration bond. Debt limits of the GDP-linked bond (GLB) refer to the actual debt limit. All figures are in percent of GDP.

assumptions used in this chapter; see the appendix). It shows that, by lengthening debt duration from say 1 year to 10 years, fiscal space may increase by some 16-39 percent of GDP, with the range governed by the extent of growth uncertainty (higher end corresponding to larger uncertainty). ${ }^{5}$ If duration increases to 20 years, gains in fiscal space are larger-on the order of 50-70 percent of GDP. These simulation results are suggestive of a significant role of maturity management in expanding fiscal space. Comparing these results with the example of GDP-linked debt, however, the table (last column) shows larger gains in fiscal space for GDP indexation than for maturity extension. ${ }^{6}$ Although the quantified gains are specific to the underlying assumptions, the results underscore that, to combat growth uncertainty, gains from GDP indexation are likely to be the more powerful instrument.

\footnotetext{
${ }^{5}$ The same caveats discussed in relation to the results in Table 1 would apply to the simulation results in Table 2.

${ }^{6}$ In the simulations in this chapter, GDP growth is the only source of uncertainty, so the GDP-linked bond fully inoculates debt dynamics against uncertainty (the debt limit is identical to the certainty case, denoted $d^{*}$ in Figure 2).
} 



\section{Chapter}

\section{Sensitivity to Underlying Assumptions}

We established in the previous chapters that debt management policy can play a powerful role in expanding fiscal space. Here we undertake a discussion of some of the underlying assumptions impacting the effects of debt management policies.

\section{Investor Risk Neutrality}

Growth-linked bonds are a state-contingent instrument that transfers debt service risk from the issuing country to investors. By issuing GLBs, the country exchanges a stream of uncertain debt service (relative to GDP) for a stream of certain debt service with equal expected value. This transfer of risk is valuable to the borrower, given the increase in fiscal space that the sovereign is able to enjoy as a result. In the model of Chapter 3, moreover, the risk-neutral investor willingly accepts the additional risk in its portfolio at zero cost, given that the expected returns from the state-contingent and non-state-contingent instruments are the same.

The assumption of risk-neutral investors is a reasonable one that has strong underpinnings in the debt literature. Large institutional investors can pool GLBs issued by multiple countries and diversify away return volatility from individual bonds by taking advantage of imperfect cross-country correlations in GDP growth rates. Indeed, idiosyncratic and diversifiable GDP variation appears to be far larger than systematic (nondiversifiable) global GDP variability (Borensztein and Mauro 2004). ${ }^{1}$ Moreover, some investors actually may be willing to charge less or even pay for additional return volatility. One such example relates to defined-benefit pension funds whose liabilities are

${ }^{1}$ Callen et al. (2015) find that the bulk of global risk-sharing gains can be achieved through asset pools involving 10 or fewer countries. 
indexed to earnings, which in turn are positively correlated with GDP. Investing in GLBs would provide a natural hedge against GDP-induced variation in their liabilities (Borensztein 2016).

While investor risk neutrality is an assumption of the model, one may wish to consider the implications if instead investors are assumed to be risk averse. Such investors would then demand a premium for accepting the additional return volatility induced by GLBs in comparison to non-state-contingent debt. To estimate the extent of such a premium, Barr et al. (2014) simulate a model that assumes a constant relative risk aversion (CRRA) utility function for investors. They find that GLBs can yield benefits in terms of increased fiscal space unless investors are exceptionally risk averse (with the coefficient of relative risk aversion greater than or equal to 24). Cabrillac et al. (2016) show by simulations that GLBs actually provide better risk diversification opportunities for international investors than equities. Kamstra and Shiller (2009) report that the risk premium for the United States would be 150 basis points at most.

We get at the issue of how investor risk aversion affects our conclusions by asking about the issuer's willingness to pay, rather than about investors' demand for compensation for risk induced by state-contingent debt. To investigate the issue, we use the model developed in Chapter 3 to determine the maximum premium that an issuing country would be willing to pay to transfer debt service risk to investors. ${ }^{2}$ Specifically, the maximum premiums are calculated as the hypothetical change in the risk-free interest rate for the GLB that would bring its debt limit down to that of the nominal bond.

Table 3 shows that the maximum premiums are on the order of 150-260 basis points, being larger the greater the underlying growth uncertainty. To put the simulated risk premiums into perspective, they need to be gauged against the underlying return volatility. A simple way to do this is to look at a variant of the Sharpe ratio, which divides the simulated risk premiums by the standard deviation of the bond yield. The reported Sharpe ratios in the case of GLBs are greater than one, and appear large relative to empirical norms of Sharpe ratios for (bond or equity) returns (which are typically well below unity), suggesting that GLBs could be attractive to investors. ${ }^{3}$ This suggests

${ }^{2}$ The premium that risk-averse investors would demand for the GLB is composed of three components: (1) a default premium; (2) a premium for contracted return volatility; and (3) a premium for the correlation risk if default is more likely in bad times when the contracted return is also low. The maximum premium derived from the model captures the last two of these three components. Since the correlation risk matters only if default risk is present, it will begin to emerge only when actual debt ratios are close to the debt limit. Moreover, the correlation risk premium would likely be small if default risk itself is small, which would be the case for the GLB.

${ }^{3}$ Estimates of unconditional Sharpe ratios for US Treasury bond portfolios are typically in the range of 0.1-0.3. Depending on the term structure model, the unconditional maximum Sharpe ratios for a complete bond market are estimated to be in the range of 0.1-0.6 (Duffee 2010). 
Table 3. Maximum Risk Premiums and Sharpe Ratios: GDP-linked Bond

\begin{tabular}{lcc}
\hline Growth Uncertainty & Risk Premium & Sharpe Ratio \\
\hline Low & 153 & 1.09 \\
High & 260 & 1.03 \\
\hline
\end{tabular}

Source: Authors' calculations.

Note: Sharpe ratio is the ratio of the risk premium to the standard deviation of the bond yield. Risk premiums are in basis points.

that premiums demanded by risk-averse investors would likely be lower than what an issuing country would be willing to pay. Unless investors are exceptionally risk averse or severely constrained in diversification opportunities, therefore, desirable risk transfer through these instruments would appear to be feasible. ${ }^{4}$ Of course, the scope of desirable risk transfer is reduced if investors are risk averse - the impact of investor risk aversion on the size of the fiscal space gains is taken up below.

As noted earlier, GLBs have rarely been issued outside a sovereign debt restructuring context. Many obstacles to issuance have been reported, ranging from data and verification issues to novelty premiums. If such obstacles are equally salient in both normal and crisis periods, an interesting question would be why GLBs have been issued at all. Our results seem to offer a possible interpretation of the greater incidence of issuance during restructuring periods. As shown in Table 3, the scope for desirable risk sharing through GLBs is larger the higher default risk or the larger the potential reduction of default risk via GLB issuance. For a given degree of investor risk aversion, there would thus be greater scope for GLB issuance when default risk is initially high. Sovereign debt restructuring is evidently a point of heightened default risk, and may provide a greater opportunity for beneficial risk sharing.

\section{Interactions among Multiple Shocks}

Stochastic variation in the debt ratio arises as a combined result of multiple shocks to debt dynamics. The impact of GLBs on the debt path and fiscal space will differ depending on the configuration of all shocks to the debt dynamics (Benford et al. (2016)). Insulating the debt dynamics against one source of uncertainty could in principle even prove counterproductive depending on the correlation across shocks. A key issue in this respect relates to the impact of the cyclicality of fiscal policy. If shocks to the primary balance are negatively correlated with the growth rate (i.e., fiscal policy is procyclical), fiscal action will tend to reduce stochastic variation in the debt ratio.

\footnotetext{
${ }^{4}$ It is worth noting that the maximum premium calculations are based on the debt limit computations of Chapter 3, which assume risk neutrality. In practice, investor risk aversion will result in a higher default premium than otherwise and a correspondingly lower debt limit for both nominal bonds and GLBs, but more so for the former. Our willingness-to-pay calculations are thus conservative by this token.
} 
Table 4. Effects of Cyclical Fiscal Policy on Fiscal Space

\begin{tabular}{llccccr}
\hline & & \multicolumn{5}{c}{ Debt Limit } \\
\cline { 3 - 6 } Growth & Fiscal Policy & Nominal & & & \\
Uncertainty & Cyclicality & Bond (A) & GLB-RN (B) & GLB-RA (C) & B - A & C - A \\
\hline \multirow{2}{*}{ Low } & Acyclical & 179.7 & 199.4 & 191.1 & 19.7 & 11.4 \\
& Countercyclical & 174.1 & 197.1 & 188.7 & 23.0 & 14.6 \\
\multirow{3}{*}{ High } & Procyclical & 184.7 & 196.8 & 188.3 & 12.1 & 3.6 \\
& Acyclical & 159.1 & 199.4 & 184.1 & 40.3 & 25.0 \\
& Countercyclical & 139.2 & 195.7 & 179.0 & 56.5 & 39.8 \\
& Procyclical & 169.8 & 190.4 & 171.0 & 20.6 & 1.2 \\
\hline
\end{tabular}

Source: Authors' calculations.

Note: The fiscal reaction function is specified as $s_{t+1}=f\left(d_{t}\right)+\beta\left(g_{t+1}-g^{*}\right)+e_{t+1}$ where $\beta$ is set to 0.4 (countercyclical) or -0.4 (procyclical), drawn from the coefficient of the output gap in the estimated primary balance equation in Ostry et al. (2010). For GLB-RN, the results for acyclical fiscal policy $(\beta=0)$ are taken from Table 1. Debt limits are in percent of GDP. In the simulation, growth uncertainty is assumed to be exogenous to fiscal policy.

In such a case, insulating debt dynamics against growth uncertainty could amplify rather than reduce stochastic variation in the debt ratio. To assess this concern, we extended the model by modifying the primary balance equation so as to allow for cyclical responsiveness of fiscal policy.

The results are reported in Table 4, for the cases of investor risk neutrality and risk aversion, respectively. ${ }^{5}$ With nominal debt, countercyclical policy $(\beta=0.4$ ) leads to a lower debt limit (relative to the case of acyclical fiscal policy), while procyclical policy $(\beta=-0.4)$ increases the debt limit. The reason is that countercyclical (procyclical) fiscal policy tends to amplify (mitigate) stochastic variation in the debt ratio caused by growth uncertainty. As a consequence, gains in fiscal space engendered by GDP-linked debt (penultimate column) are largest under countercyclical fiscal policy and smallest under procyclical policy. Under high uncertainty, for instance, the gain in fiscal space is 56 percent of GDP under countercyclical policy but falls to 21 percent under procyclical fiscal policy. Finally, gains in fiscal space are smaller if investors are risk averse (last column), falling to 40 percent of GDP in the high-uncertainty, countercyclical case, and becoming negligible in the case of procyclical policy.

\section{Debt Composition and Marginal Gains in Fiscal Space}

The discussion in the foregoing sections assumed corner solutions in which the government issued only nominal bonds or entirely GLBs. How would

\footnotetext{
${ }^{5}$ The simulations assume that the premiums demanded by risk-averse investors are 70 and 126 basis points, corresponding to the low- and high-growth-uncertainty cases, respectively. The premiums are constructed by applying a Sharpe ratio of 0.5 to the simulated maximum risk premiums reported in Table 3 .
} 
Table 5. Marginal Gains in Fiscal Space and the Share of GLBs

\begin{tabular}{lccccc}
\hline Growth & Debt Limit & \multicolumn{4}{c}{ Marginal Gain in Fiscal Space } \\
\cline { 3 - 6 } Uncertainty & $(\omega=\mathbf{0})$ & $\omega=\mathbf{1 / 4}$ & $\omega=\mathbf{1 / 2}$ & $\omega=\mathbf{3 / 4}$ & $\omega=\mathbf{1}$ \\
\hline Low & 179.7 & 6.4 & 5.4 & 4.5 & 3.4 \\
High & 159.1 & 13.6 & 11.1 & 9.7 & 5.9 \\
\hline
\end{tabular}

Source: Authors' calculations.

Note: $\omega$ is the share of GDP-linked debt out of total debt. Reported debt limits for $\omega=0$ are for nominal debt taken from Table 1. Marginal gains in fiscal space reported for $\omega=1 / 4$ refer to gains resulting from an increase in $\omega$ from 0 to 1/4; Likewise, marginal gains reported for $\omega=1 / 2$ are gains from an increase in $\omega$ from $1 / 4$ to $1 / 2$. All figures are in percent of GDP.

things change if, as seems more likely, there was a mixed portfolio involving both types of instrument?

To quantify the marginal gains in fiscal space brought about by a change in the debt composition, we simulate the model under different assumptions about the initial share of GLBs in total debt (while focusing on the case of neutral fiscal policy with $\beta=0$ ). Table 5 presents results for three interim values of this share (denoted by $\omega$ ). Simulated debt limits are increasing in the share of GLBs, and, as a result, reported marginal gains in fiscal space are all positive. The table also shows that the marginal gain in fiscal space is diminishing as the share of GLBs increases. Under high growth uncertainty, for instance, fiscal space increases by 14 percent of GDP when the share of GLBs increases from 0 to 25 percent. But the marginal gains in fiscal space decline to 11 percent GDP and 10 percent of GDP as the share increases to 50 percent and further to 75 percent, respectively. The intuition for diminishing marginal gains is simple: growth uncertainty matters progressively less for fiscal space as the share of GLBs increases, simply because there is less nominal debt. 



\section{Chapter}

\section{(2) Conclusion}

We have shown that debt management policies can play a significant role in expanding fiscal space. Specifically, issuing state-contingent debt such as GDP-linked bonds can help to stabilize debt ratios by inoculating debt dynamics against growth uncertainty. Likewise, increasing debt duration can also lead to less volatile debt ratios and, thus, to larger fiscal space. Implications may be broader since any debt management policy that stabilizes debt ratios under uncertainty could help to increase fiscal space.

Several policy implications flow from the analysis. GLBs may be attractive to both emerging market economies where growth volatility is high, and to advanced economies with elevated debt ratios and limited maneuver to undertake countercyclical monetary policy. Our analysis shows that reducing stochastic variation in the debt ratio has a larger impact on fiscal space the larger the extent of growth uncertainty and the higher the actual debt ratio. It also suggests that there is scope for significant gains in fiscal space when GLBs account for only a negligible share of total debt, as at present. One should expect reduced scope for risk sharing between sovereign and investors if investors demand a premium for return volatility in GLBs or a term premium for longer maturities. Our simulations suggest, however, that the risk-sharing benefit of GLBs is plausible unless investors are exceptionally risk averse or the opportunity for risk diversification is significantly constrained. On the investor side, GLBs would be especially attractive to defined-benefit pension funds because these instruments provide a natural hedge against GDP-induced variation in pension liabilities.

Policy challenges are not trivial, however. Political commitment to countercyclical fiscal policy would be necessary to reap the benefit from GLBs, given that debt service is procyclical. Countries should also be mindful of the financial-stability implications of risk migration from the sovereign to private investors that issuance of state-contingent instruments may entail. 
Our analysis shows that the underlying mechanism by which GDP-linked debt helps to increase fiscal space is indeed risk sharing between the sovereign and private investors. The issue of risk migration becomes more pertinent in a closed-economy setting where growth uncertainty is a nondiversifiable risk. It has been the conventional wisdom that the government is a better risk absorber than the private sector given its taxation powers. On this view, issuance of GLBs by the sovereign could undermine financial stability, rather than improve it. Our sense, however, is that the shock-absorbing capacity of the government depends on the sovereign retaining fiscal space to allow it to absorb risk. This case for GLBs and other debt management policies to enhance fiscal space seems relevant in situations where fiscal space is limited, i.e., where the shock-absorbing capacity of the government is constrained.

Moreover, risk migration is not an issue solely for GDP-linked debt or other state-contingent instruments — as the example of long-term (nominal) debt discussed in this paper shows. This result suggests that some risk migration from the sovereign to private investors is already at work in advanced economies. The recent fiscal insurance literature provides a clue as to the extent of risk migration that long-term debt might induce in practice. For example, Berndt et al. (2012) find that, in the post-war period, about 9 percent of the US government's unanticipated defense spending needs were financed by a reduction in the market value of debt; the relatively long maturity of public debt in the United Kingdom (in comparison, say, to the United States), is also suggestive. Given this evidence, our sense is that concerns about risk migration should not be overstated as an impediment to issuance of state-contingent public debt instruments at the current juncture, in either advanced or emerging market economies. 


\section{Appendix: Determination of Debt Limit under Uncertainty}

This appendix sketches the model used in the analysis and explains how the debt limit is determined under uncertainty. It also discusses briefly how simulations are undertaken for the long-duration bond.

\section{The Model}

The GDP growth rate $(g)$ is distributed according to the cumulative probability distribution $G(g)$, defined over the finite support $\left[g_{L}, g_{H}\right]$ with mean equal to $g^{*}$. The primary balance as a share of GDP is constant at $s^{*}$. Investors are risk neutral and recover nothing upon default. The government issues debt in bonds. The following three types of bonds are considered: one-period nominal bond, one-period GDP-linked bond (GLB), and long-duration nominal bond.

One-period nominal bond: Total payout at maturity is fixed to one dollar. The debt dynamics equation and the bond price $(q)$ can be expressed as follows:

$$
\begin{aligned}
& d_{t+1}=\left(d_{t} / q_{t}\right) /\left(1+g_{t+1}\right)-s^{*} \\
& q_{t}=\left(1-p_{t+1}\right) /\left(1+r^{*}\right)
\end{aligned}
$$

where $d$ refers to the debt-to-GDP ratio, $p$ is the default probability, and $r^{*}$ is the constant risk-free interest rate. By using the probability distribution function $G(g)$, the default probability defined in equation (2) in the main text can be rewritten as a fixed-point problem:

$$
p_{t+1}=G\left(H\left(p_{t+1} ; d_{t}, \bar{d}\right)\right), H\left(p_{t+1} ; d_{t}, \bar{d}\right)=\left(\frac{d_{t}}{\bar{d}+s^{*}}\right)\left(\frac{1+r^{*}}{1-p_{t+1}}\right)-1
$$

where $H$ is the threshold for the growth rate below which default occurs in the next period. An interior solution (i.e., $p_{t+1}<1$ ) to this problem determines the bond price in equilibrium, while $p_{t+1}=1$ is always a (corner) solution-the solution with certain default.

Since $H$ is increasing in $d_{t}$, the default probability must rise as the debt ratio approaches the debt limit from below. If $d_{t}$ is low enough that $H\left(0 ; d_{t}, \bar{d}\right)$ $<g_{L}$, then $p_{t+1}=0$ is the equilibrium solution. Conversely, if $d_{t}$ is high enough that $H\left(0 ; d_{t}, \bar{d}\right)>g_{H}, p_{t+1}=1$ is the only (corner) solu- 
tion. The debt limit, denoted by $\bar{d}_{1}$, is determined by requiring that the default probability solves the fixed-point problem in (A.3), and that it must be strictly less than unity at or below the debt limit and unity otherwise. Technically, it is determined by the largest value of $\bar{d}$ for which $p_{t+1}=G\left(H\left(p_{t+1} ; \bar{d}, \bar{d}\right)\right)$ has an interior solution. At the debt limit (i.e., $\left.d_{t}=\bar{d}_{1}\right)$, therefore, the debt ratio remains unchanged in the next period (i.e., $\left.d_{t+1}=\bar{d}_{1}\right)$ only if $g_{t+1}=H\left(p_{t+1} ; \bar{d}_{1}, \bar{d}_{1}\right)$. If the realized growth rate is higher than the threshold $H$, no default occurs since the debt ratio falls below the debt limit in the next period. Otherwise, the debt ratio exceeds the debt limit and default occurs.

In the certainty case where the growth rate is constant at $g^{*}$, the debt dynamics equation in (A.1) reduces to

$$
d_{t+1}-d_{t}=\left[\left(r^{*}-g^{*}\right) /\left(1+g^{*}\right)\right] d_{t}-s^{*}
$$

The debt limit in this case, $d^{*}$, is determined by setting $d_{t+1}-d_{t}=0$, which yields, $d^{*}=\left[\left(1+g^{*}\right) /\left(r^{*}-g^{*}\right)\right] s^{*}$.

One-period GDP-linked bond (GLB): Total payout at maturity is set to $\rho_{t+1}=\left(1+g_{t+1}\right) /\left(1+g^{*}\right)$, the expected value of which is equal to one dollar in the absence of default risk. Given this GDP-linked total payout, the debt dynamics equation and the bond price are expressed as:

$$
\begin{aligned}
& d_{t+1}=\rho_{t+1}\left(d_{t} / q_{t}\right) /\left(1+g_{t+1}\right)-s^{*}=\left(d_{t} / q_{t}\right) /\left(1+g^{*}\right)-s^{*} \\
& q_{t}=\int_{g_{L}}^{g_{H}}\left[1-p_{t+1}^{C}\left(g_{t+1}\right)\right] \rho_{t+1} d G(g) /\left(1+r^{*}\right)
\end{aligned}
$$

where $p_{t+1}^{C}\left(g_{t+1}\right)$ refers to the conditional default probability. The last equality in (A.5) shows that debt dynamics no longer depend on growth uncertainty, which in turn implies that conditional default probabilities are independent of the growth rate. Substituting $p_{t+1}^{C}\left(g_{t+1}\right)=p_{t+1}$ into (A.6) yields:

$$
q_{t}=\left(1-p_{t+1}\right) \int_{g_{L}}^{g_{H}} \rho_{t+1} d G(g) /\left(1+r^{*}\right)=\left(1-p_{t+1}\right) /\left(1+r^{*}\right)
$$

Since the primary balance is constant by assumption, debt dynamics involve no uncertainty. As a result, $p_{t+1}=0$ and $q_{t}=1 /\left(1+r^{*}\right)$ for the GLB. This result readily implies that the debt limit for the GLB is the same as $d^{*}$, the debt limit of the nominal bond in the certainty case.

Proof that $\overline{\boldsymbol{d}}_{1} \leq \boldsymbol{d}^{*}$ : For the proof, it is assumed that $G(g)$ is symmetric around its mean, and that $g_{H}-2 g^{*}<1$. It suffices for the proof to show that 
the fixed-point problem in (A.3) has only the corner solution (i.e., $p_{t+1}=1$ ) at $d_{t}=\bar{d}=d^{*}$, where $d^{*}=\left(1+g^{*}\right) s^{*} /\left(r^{*}-g^{*}\right)$ is the debt limit of the GLB. Substituting $d_{t}=\bar{d}=d^{*}$ into (A.3) yields:

$$
p_{t+1}=G\left(H\left(p_{t+1}\right)\right), H\left(p_{t+1}\right)=\left(p_{t+1}+g^{*}\right) /\left(1-p_{t+1}\right)
$$

It is straightforward to show that:

$$
H^{\prime}\left(p_{t+1}\right) \geq 0, H(0)=g^{*} \text {, and } H\left(\frac{1}{2}\right)=1+2 g^{*}>g_{H}
$$

These properties of $H$ immediately imply that $p_{t+1}<G\left(H\left(p_{t+1}\right)\right)$ for all $p_{t+1} \in[0,1)$. Consequently, the fixed-point problem in (A.8) has no interior solution but only the corner solution (i.e., $p_{t+1}=1$ ) at $d_{t}=\bar{d}=d^{*}$. This completes the proof that the debt limit is higher for the GLB than for the nominal bond.

The debt limit of the nominal bond is lower the larger the extent of uncertainty. To see this, let $\tilde{G}(g)$ stand for a mean-preserving spread of $G(g)$. Then, $\tilde{G}(H)>G(H)$ whenever $H<g^{*}$. Thus, the default probability that satisfies (A.3) must be larger under $\tilde{G}(g)$ than $G(g)$, provided that $H<g^{*}$ in equilibrium (or, equivalently, $p_{t+1}<0.5$ at the debt limit). This implies that the debt service schedule bends upward earlier and more steeply, which results in a lower debt limit.

Long-duration nominal bond: The long-duration bond issued at time $t$ promises to pay from $t+1$ onward an infinite stream of (geometrically decaying) coupons, $c_{t+k}=(1-\delta)^{k-1}$ for $k \geq 1$, where $0<\delta \leq 1$. In the absence of default risk, the (Macaulay) duration of the bond is $\left(1+r^{*}\right) /(\delta+$ $\left.r^{*}\right)$, and the bond price is given by $q^{*}=1 /\left(\delta+r^{*}\right)$. The one-period nominal bond considered above corresponds to setting $\delta=1$. Duration is longer than one period if $\delta<1$.

Given this specification of the long-duration bond, the standard debt dynamics equation is written for the gross financing need (GFN), which differs from the debt ratio if duration is longer than one period. Letting $b$ and $x=b-s^{*}$ stand, respectively, for coupon payment obligations (hereafter, debt service obligations) and the GFN, both as a share of GDP, the law of motion for the GFN is expressed as follows:

$$
x_{t+1}=\left(x_{t} / q_{t}\right) /\left(1+g_{t+1}\right)+(1-\delta) b_{t} /\left(1+g_{t+1}\right)-s^{*}
$$


The first term on the right-hand side is the required debt service arising from newly issued debt at time $t$, while the second term captures debt service associated with the previously issued debt.

The debt ratio for the long-duration bond, $d_{t}$, is defined as the ratio of the market value of the stock of debt to GDP. In equilibrium, $d_{t}$ must be equal to the sum of the coupon payment at time $t$ and the present value $(P V)$ of all future coupon payments (all as a share of GDP at time $t$ ), net of the current period primary balance:

$$
d_{t}=b_{t}+P V\left\{(1-\delta) b_{t},(1-\delta)^{2} b_{t},(1-\delta)^{3} b_{t}, \ldots\right\}-s^{*}
$$

where the present value is evaluated taking into account the default risk. By using the bond price, the present value term can be succinctly summarized by $P V=(1-\delta) q_{t} b_{t}$. Using this expression for $P V$, the debt ratio of the long-duration bond is obtained as:

$$
d_{t}=\left[1+(1-\delta) q_{t}\right] b_{t}-s^{*}=\left[1+(1-\delta) q_{t}\right] x_{t}+(1-\delta) q_{t} s^{*}
$$

where the second equality follows from $x_{t}=b_{t}-s^{*}$. As long as the bond price falls with the GFN ratio-which is the case if default risk is present-a 1 percentage point increase in the GFN ratio leads to a less than 1 percentage point increase in the debt ratio (i.e., $\partial d_{t} / \partial x_{t}<1$ ), confirming the well-known hedging benefit of long-term debt.

The price of the long-duration bond is given by:

$$
q_{t}=\left(1-p_{t+1}\right)\left[1+(1-\delta) q_{t+1}^{E}\right] /\left(1+r^{*}\right)
$$

where $q_{t+1}^{E}=E_{t}\left[q_{t+1} \mid q_{t+1}>0\right]$ is the expected bond price in the next period in a no-default state (where bond prices are strictly positive). For the long-duration bond $(\delta<1)$, future bond prices affect the current price via the term $q_{t+1}^{E}$; this term is absent for the one-period bond $(\delta=1)$.

Given the finite primary balance, there exists a finite GFN limit, $\bar{x}$, beyond which the debt dynamics become unsustainable. The default probability defined as $p_{t+1}=\operatorname{Pr}\left[x_{t+1}>\bar{x}\right]$ constitutes a fixed-point problem because $x_{t+1}$ depends on $p_{t+1}$. According to (A.10), the debt limit for the long-duration bond, $\bar{d}$, can be expressed as $\bar{d}=[1+(1-\delta) \bar{q}] \bar{x}+(1-\delta) \bar{q} s^{*}$, where $\bar{q}$ is the bond price at the GFN limit. By using this relationship and 
the probability distribution function $G(g)$, the fixed-point problem for the default probability can be rewritten as:

$$
p_{t+1}=G\left(Z\left(p_{t+1} ; d_{t}, \bar{d}\right)\right), Z\left(p_{t+1} ; d_{t}, \bar{d}\right)=\left(\frac{d_{t}}{\bar{d}+s^{*}}\right)\left(\frac{1+r^{*}}{1-p_{t+1}}\right) Q_{t}-1
$$

where $Q_{t}=[1+(1-\delta) \bar{q}] /\left[1+(1-\delta) q_{t+1}^{E}\right]>0$, and $Z$ represents the threshold growth rate below which default occurs in the next period. The term $Q_{t}$ captures the favorable effect on the current bond price of future upside shocks to growth, which, among other things, push up future bond prices.

Given this fixed-point problem, the following two equilibrium conditions determine the debt limit of the long-duration bond:

$$
\begin{aligned}
& p_{t+1}<1 \text { if } d_{t+1} \leq \bar{d} \text { and } p_{t+1}=1 \text { otherwise } \\
& q_{t+1}^{E}=\left(1-p_{t+1}\right)^{-1} \int_{Z}^{g_{H}} q_{t+1} d G(g)
\end{aligned}
$$

where $p_{t+1}$ solves the fixed-point problem in (A.12). The first condition requires that the default probability jump to unity as soon as debt exceeds the debt limit, while the second condition requires that $q_{t+1}^{E}$ be the rational expectation of the bond price in the next period conditional on no default. Technically, the debt limit is determined by the largest value of $\bar{d}$ for which $p_{t+1}=G\left(Z\left(p_{t+1} ; \bar{d}, \bar{d}\right)\right)$ has an interior solution. It is important to observe that $Q_{t}=1$ at all times for the one-period bond but $Q_{t}<1$ for the long-duration bond for all debt ratios (at or below the debt limit) for which default risk is present, because $\bar{q}$ is by definition the lowest possible positive price in equilibrium while $q_{t+1}^{E}$ is the expected value of positive bond prices only. This observation implies that the fixed-point problem in (A.12) has an interior solution at a debt ratio higher than the debt limit for the one-period bond. This proves that the long-duration bond yields a higher debt limit than the one-period bond.

By using (A.10), the law of motion for the GFN in (A.9) can be rewritten as:

$$
\left[1+(1-\delta) q_{t}\right]\left(x_{t+1}-x_{t}\right)=\left[\left(r_{t}-g_{t+1}\right) /\left(1+g_{t+1}\right)-A_{t+1}\right] d_{t}-s^{*}
$$

where $r_{t}=\left(r^{*}+p_{t+1}\right) /\left(1-p_{t+1}\right)$ and $A_{t+1}=(1-\delta)\left(q_{t+1}^{E} / q_{t}-1\right) /(1+$ $\left.g_{t+1}\right)$. This equation shows that the GFN ratio will be rising whenever the primary balance $\left(s^{*}\right)$ falls short of the required debt service, $\left[\left(r_{t}-g_{t+1}\right) /\right.$ $\left.\left(1+g_{t+1}\right)-A_{t+1}\right] d_{t}$. It can be shown that $A_{t+1}=0$ if the debt ratio is sufficiently low that no default risk arises (which is the case if debt lies below the 
natural debt limit, $\bar{d}_{n}=\left(1+g_{L}\right) s^{*} /\left(r^{*}-g_{L}\right)$, and $A_{t+1}>0$ for higher debt ratios. Thus, the required debt service increases, on average, less rapidly with debt than in the case of the one-period bond (for which $A_{t+1}=0$ for all $t$ )—see Figure 2.

In the absence of growth uncertainty, $p_{t_{*}+1}=A_{t+1}=0$ at or below the debt limit, in which case $r_{t}=r^{*}$ and $q_{t}=q^{*}$. Given these values and (A.10),

(A.14) reduces to:

$$
d_{t+1}-d_{t}=\left[\left(r^{*}-g^{*}\right) /\left(1+g^{*}\right)\right] d_{t}-s^{*}
$$

Setting $d_{t+1}-d_{t}=0$ yields the debt limit of the certainty case, $d^{*}=[(1+$ $\left.\left.g^{*}\right) /\left(r^{*}-g^{*}\right)\right] s^{*}$, which is identical to the debt limit of the one-period bond in the certainty case. This establishes that debt duration does not matter for the debt limit if there is no uncertainty.

\section{Simulation for Long-duration Bond}

As is common in rational expectations models, multiple equilibria emerge in the model because of the feedback from future to current prices as shown in (A.11). At a given debt ratio, a higher value of $q_{t+1}^{E}$ increases the current bond price. For any realized growth rate, this will lead to a lower debt ratio and a higher bond price in the next period. As a result, the higher value of $q_{t+1}^{E}$ becomes justified ex post. To pin down the debt limit, it is assumed that investors use a common, sensible equilibrium selection rule under which the equilibrium price of the long-duration bond is lower the higher the debt ratio.

According to the model, $q_{t+1}^{E}$ at the debt limit can always be expressed as a weighted average of $\bar{q}$ and the risk-free price $q^{*}$ :

$$
q_{t+1}^{E}=\alpha \bar{q}+(1-\alpha) q^{*}, 0<\alpha<1
$$

given that $q_{t+1}^{E}$ must be higher than $\bar{q}$ (the lowest possible positive bond price) but must always be less than the risk-free price $\left(q^{*}\right)$, which is the highest possible bond price. As $\alpha$ approaches unity (i.e., $q_{t+1}^{E}$ converges to $\bar{q}$ ), the debt limit of the long-duration bond converges to the one-period debt case, because the fixed-point problem in (A.12) reduces to that for the one-period bond shown in (A.3) when $Q_{t}$ converges to unity. In the simulation, $\alpha$ is restricted to be greater than 0.5 . This restriction rules out excessively optimistic expectations about future prices. In addition, an additional technical 
restriction is introduced that $q_{t+2}^{E}=q_{t+1}^{E}$ at the debt limit, despite the fact that the model implies $q_{t+2}^{E} \geq q_{t+1}^{E}$ in equilibrium. This in turn leads to a lower value of the bond price at the debt limit $(\bar{q})$ than implied by the model. The simulated debt limit is correspondingly lower than implied by the model. To see this, the fixed-point problem in (A.12) can be rewritten as:

$$
p_{t+1}=G\left(W\left(p_{t+1} ; x_{t}, \bar{x}\right)\right), W\left(p_{t+1} ; x_{t}, \bar{x}\right)=\left(\frac{x_{t}}{\bar{x}+s^{*}}\right)\left(\frac{1+(1-\delta) q_{t}}{q_{t}}\right)-\left(\frac{\bar{x}+\delta s^{*}}{\bar{x}+s^{*}}\right)
$$

where $\bar{x}$ is the GFN limit, and $W$ depends on $p_{t+1}$ via the bond price $q_{t}$. Since $W$ is decreasing in $q_{t}$, the maximum interior solution of this problem is obtained at a lower level of the GFN, denoted by $x^{\prime}$, than the limit implied by the model, if $\bar{q}$ is restricted to be lower than its theoretical value. The simulated value of $x^{\prime}$ constitutes a lower bound of the GFN limit, and can be translated into a corresponding lower bound of the debt limit of the long-duration bond by using (A.10).

Finally, the simulations for long-duration bond assume a constant primary balance ( 4 percent of GDP) and a truncated normal distribution for the growth rate defined over the finite interval $\left[g^{*}-1.96 \sigma, g^{*}+1.96 \sigma\right]$, where $g^{*}=2.4$ percent, and $\sigma=1.4$ percent in the low-uncertainty variant and 2.5 percent in the high-uncertainty variant. The risk-free interest rate and the recovery value are set to 4.4 percent and 90 percent, respectively. 


\section{References}

Abiad, A. and J. Ostry, 2005, "Primary Surpluses and Sustainable Debt Levels in Emerging Market Countries," IMF Policy Discussion Paper, No. 05/6 (Washington: International Monetary Fund).

Angeletos, Marios, 2002, "Fiscal Policy with Noncontingent Debt and the Optimal Maturity Structure," Quarterly Journal of Economics, 117, pp. 1105-1131.

Arellano, C., and A. Ramanarayanan, 2012, "Default and the Maturity Structure in Sovereign Bonds,” Journal of Political Economy, 120 (2), pp.187-232.

Bank of England, 2016, "Making a Reality of GDP-linked Sovereign Bonds," Concept note submitted to the G-20 ministerial meeting. (available at: http:/g20chn.org/English/ Documents/Current/201608/t20160819_3167.html)

Barr, D., O. Bush and A. Pienkowski, 2014, "GDP-linked Bonds and Sovereign Default," Working Paper No. 484, Bank of England.

Barro, Robert, 1995, “Optimal Debt Management,” NBER Working Paper No. 5327

Benford, J., T. Best, and M. Joy, 2016, “Sovereign GDP-linked bonds," Financial Stability Paper, No. 39, Bank of England.

Benjamin, D., and M. Wright, 2009, "Recovery Before Redemption? A Theory of Delays in Sovereign Debt Renegotiations," Center for Macroeconomic Analysis Working Paper $15 / 2009$.

Berndt, D., H., Lustig, and S. Yeltekin, 2012, "How Does the US Government Finance Fiscal Shocks?”, American Economic Journal, Vol 4, Issue1, pp. 69-104.

Blanchard, O., P. Mauro, and J. Acalin, 2016, "The case for Growth-Indexed Bonds in Advanced Economies Today," mimeo. (available at: https://piie.com/system/files/ documents/pb16-2.pdf)

Bohn, Henning, 2008, “The Sustainability of Fiscal Policy in the United States," in Sustainability of Public Debt, ed. by Reinhard Neck and Jan-Egbert Sturm, pp.15-49 (Cambridge, Massachusetts; MIT Press).

Borensztein, Eduardo, 2016, “GDP-Linked Debt: Lesson and Options,” mimeo.

Borensztein, E. and P. Mauro, 2004, “The Case for GDP-Indexed Bonds," Economic Policy, Vol. 19, No. 38, April

Borensztein, E., M. Chamon, O. Jeanne, P. Mauro, and J. Zettelmeyer, 2004, Sovereign Debt Structure for Crisis Prevention, IMF Occasional Paper 237 (Washington: International Monetary Fund) 
Broner, F., G. Lorenzoni and S. Schmukler, 2013, "Why Do Emerging Economies Borrow Short Term?" Journal of the European Economic Association, 11, pp. 67-100.

Cabrillac, B., L., Gauvin, and J. Gosse, 2016, "GDP-indexed bonds: What are the benefits for issuing countries, investors and international financial stability?” Quarterly Selection of Articles, Banque de France, No. 44, Winter 2016-2017, pp. 5-18.

Callen, M, J. Imbs, and P. Mauro, 2015, “Pooling Risk among Countries," Journal of International Economics, Vol. 96(1), pp. 88-99.

Chamon, M. and P. Mauro, 2006, "Pricing Growth-Indexed Bonds," Journal of Banking and Finance, 30 (December), pp 3,349-66.

Chatterjee, S., and B. Eyigungor, 2012, "Maturity, Indebtedness, and Default Risk," American Economic Review, 102 (6), pp. 2674-2699.

Council of Economic Advisors, 2004, "Growth-Indexed Bonds: A Primer," available at: http://web.mit.edu/kjforbes/www/Shorter\%20Articles/Growth-Indexed\%20Bonds-A\%20 Primer.pdf

Drèze, Jacques, 2000, "Economic and Social Security in the Twenty-First Century, with Attention to Europe," Scandinavian Journal of Economics, Vol. 102(3), pp 327-348.

Duffee, Gregory, 2010, "Sharpe ratios in term structure models," available at: http://econ. jhu.edu/People/Duffee/duffeeSharpe.pdf

Durdu, Ceyhun Bora, 2009, "Quantitative Implications of Indexed Bonds in a Small Open Economies," Journal of Economic Dynamics and Control, Vol. 33, pp 883-902.

Greenwood, R., S. Hanson and J. Stein, 2015, "A Comparative-Advantage Approach to Government Debt Maturity,” Journal of Finance, 70 (4), pp. 1683-1722.

Griffith-Jones, S. and K. Sharma, 2005, “GDP-Indexed Bonds: Making It Happen,” United Nations Department of Economics and Social Affairs Working Paper 21 (April)

Hatchondo, J., and L. Martinez, 2009, "Long-duration Bonds and Sovereign Defaults," Journal of International Economics, 79 (1), pp. 117-125. , 2012, "On the Benefits of GDP-Indexed Government Debt: Lessons from a Model of Sovereign Defaults," Economic Quarterly, Vol. 98, No. 2, pp. 139-157.

International Monetary Fund, 2016, "Assessing Fiscal Space: An Initial Consistent Set of Considerations," IMF Policy Paper (Washington).

Jeanne, O., 2009, "Debt Maturity and the International Financial Architecture," American Economic Review, 99 (5), pp. 2135-2148.

Kamstra, M. and R. Shiller, 2009, "The Case for trills," Cowles Foundation Discussion Paper, No. 1717. 
Kruse, S., M. Meitner, and M. Schroder, 2005, "On the Pricing of GDP-linked Financial Products," Applied Financial Economics, Vol. 15, No. 17, pp. 1125-1133.

Mendoza, E., and J. Ostry, 2008, "International evidence on fiscal solvency: Is fiscal policy responsible?” Journal of Monetary Economics, Vol. 55, pp. 1081-1093

Missale, A., and O. Blanchard, 1994, "The Debt Burden and Debt Maturity," American Economic Review, 84 (1), pp. 309-319.

Miyajima, Ken, 2006, "How to Evaluate GDP-Linked Warrants: Price and Repayment Capacity,” IMF Working Paper, WP/06/85 (Washington: International Monetary Fund).

Obstfeld, M. and G. Peri, 1998, "Regional Non-adjustment and Fiscal Policy," Economic Policy, April, pp. 207-259.

Onder, Yashin, 2016, “GDP-Indexed Bonds in Perpetuity and Sovereign Default," Working Paper, Central Bank of Turkey.

Ostry, J., A. Ghosh, J. Kim, and M. Qureshi, 2010, "Fiscal Space," IMF Staff Position Note, SPN/10/11 (Washington: International Monetary Fund).

Shiller, Robert, 1993, Macro Markets: Creating Institutions for Managing Society's Largest Economic Risks, Oxford University Press, Oxford. 